\title{
A Study on Customer Loyalty and Customer Retention in Online Shopping
}

\author{
Ms. ThakreemBanu ${ }^{\mathrm{a}}$ \\ \{arv.afd@psgtech.ac.in $\left.{ }^{1}\right\}$ \\ Msc Fashion Design \& Merchandising, Department of Apparel and Fashion Design, PSG College of \\ Technology, Coimbatore-641004, India. ${ }^{a}$, Assistant Professor, Department of Apparel and Fashion \\ Design, PSG College of Technology, Coimbatore-641004, India. ${ }^{\text {b }}$
}

\begin{abstract}
Marketing is making a transition from transactional marketing to relational marketing. The world has become a global village, leading to a highly competitive market, giving customers to choose from a wide variety of the options. This has caused fashion brands selling similar goods to adopt innovative methods to draw in customers.Relationship marketing approach are the most commonly used method to ensure customerloyalty. It is defined as the concept of creating, maintaining and upgrading strong relationships with customer. It is also observed that effective relationship marketing strategy helps the organization to understand the customer's needs, thus enabling them to serve the customers leading to cost reduction and customer loyalty. This paper studies the effectives of the relationship marketing techniques adopted by Myntra. It was observed that the programmes offered by Myntra are well know to its customers and is popular too. The relationship marketing strategies should be in way that increases customer loyalty and customer retention as exhibited by Myntra.
\end{abstract}

Keywords: Relationship Marketing, Customer Relationship Management,Relational benefits, Customer loyalty.

\section{Introduction}

Relationship marketing in today's generation can be defined as the facet of customer relationship management that focuses on customer loyalty and long-term customer engagement instead of shorter-term goal like customer acquisition and individual sales. Fashion markets are characterized increasingly short product life cycles and demand uncertainties. Fashion markets are characterized increasingly short product life cycles and demand uncertainties. Modern fashion brands like Louis Vuitton or Chanel have built their initial success within an in-depth community of fans. Many creators use the entertainment industry as a stepping stone to success in their initial stages.

\section{A. Relational benefits provided by Fashion brands}

The fashion customers in the current market expect brands to fulfill additional requirements along with the core services [1]. The customers choose to cultivate long term relationships only when the above criteria are satisfied. The relational benefits are classified in to two categories social and functional.The functional benefits include savings in time, convenience of shopping, providing advice on fashion and purchase decisions. Social benefits included enjoying the interaction with sales personnel [1]. Customers consider preferential 
treatment as elevated social status. It is studied that special treatment is a major factor in satisfying and retaining customers as the customers compare themselves with fellow shoppers and enjoy the recognition from the service providers[2].

F. Thakreem Banu is a $5^{\text {th }}$ year student of the programme Msc Fashion Design \& Merchandising, Department of Apparel and Fashion Design, PSG College of Technology, Coimbatore-641004, India.

S. B. Ms. A Ragavi, Assistant Professor, Department of Apparel and Fashion Design, PSG College of Technology, Coimbatore-641004, India. (e-mail: arv.afd@psgtech.ac.in)

\section{B. Customer Relationship Management}

Customer Relationship Management (CRM), is an approach that helps businesses improve existing customer relationships and acquire new customers faster. Brick \& Mortar stores have established mechanism of membership cards to introduce or enhance CRM initiatives [3]. These cards provide valuable information on the customers and are utilized to understand the needs and wants of customers [4].Some of the benefits include updating the customers on specific offers or special discounts provided by the retailer. Thee commerce sites use CRM to gather data about all contactsthey have has with their customer to enable them to really understand customer action [5].

\section{Customer Loyalty and Customer Loyalty programmes}

Studies in the past years have proved that relationship marketing efforts improves both customer loyalty and fashion brands performance through stronger relational bonds. Fashion loyalty programs are customer retention tools. There are many programmes available and brands are constantly trying to adopt innovative and best strategy to appeal to their customers.[5] The most common loyalty programme is membership cards. Brands have used their customer loyalty program to make a real difference on a global scale. A popular customized brand Toms choose a new method of loyalty program by appealing to their customer's values and sense of worth. With every purchase, customers earn the non-monetary incentive of making change through various initiatives that serve a social cause.

\section{Myntra's relationship with their customers}

Myntra.com established by Mukesh Bansal, Ashutosh Lawani and Vineet Saxena in February 2007 is ranked among the topten e-commerce companies in India. Myntra's value proposition revolves around giving consumers the facility and simple purchasing fashion and lifestyle products online. Myntra with the help of its focused customer experience team, introduces structured programs to surprise their customers and enhance their experience.This has enhanced the relationship between the brand and the customer.[6] One of the recent programs introduced by Myntra is the 'Customer WOW' program. In this program around 150 shoppers are picked by the team and delight the customerswith gifts, personalized notes, etc. The e-commerce is popular for its 30 days exchange policy, which was the introduced when the customer experience team realized that nearly $80 \%$ of consumers were requesting returns because they wanted a special size[6].

\section{E. Myntra's features}

Myntra.com has introduced some features for making its business model impressive, unique and popular among the consumers. These features are as follows: 
1. Automatic Search Functionality for Filters: Functionality of product searching in Myntra app is easy \& convenient for satisfying customer's queries.

2. Instant Sending of Gift Cards: Myntra.com provides new concept of gift cards, which user can instantly send to their loved ones with special gift wrap facility at a nominal cost to spread the happiness and feeling of joy.

3. Instant Product Cancellation: Instant product cancellation is a best feature of Myntra.com.If the customers want to change or cancel the product, they have option available in orders section, by selecting that, a customer can cancel order instantly without any problem.

4. Facility to Follow Famous Brands \&Lifestyle Fashion Bloggers: With the help of Myntra online app customers can create their profile and can associate with the fashion community and can follow fashion brands or style icons.

5. Select Perfect then Shop: Myntra online app has introduced this feature, where customers can share pictures of their explored and selected products with family and friends for taking suggestions to pick one to buy from many items.

6. First Try Then Buy: The main hesitation of buyers to purchase online is, they are not sure about different brand's sizes also, so they are confused with the time of ordering.Myntra solves this problem by introducing Try and Buy feature [6].

\section{F. Myntra's customer loyalty programs:}

Myntra has launched two loyalty programs to extend the traffic and engagement on its website and mobile app.The program avail benefits like early access to sales or points to get products. Some other benefits include experiences like styling, fashion assistant, among others.Customers get rewarded for visiting Myntra, for providing reviews and ratings. This will cause more retention, more repeat visits and fewer uninstalls.Myntra has launched its another loyalty program during COVID-19, Which is named as 'Myntra move'.Myntra launched Myntra move as a objective to keep their customers Healthy and Fit during COVID19.Myntra Move is related to steps.In this program,the customers have to move, and exercise to increase the steps on Myntra app in return of this Myntra gives their customers Myntra insider point, once the customer gets required insider point,they can redeem it and buyMyntra voucher.

\section{G. Myntra campaign: Go Myntra la-la}

In the pursuit of reaching out to a larger number of consumers in the country and to spread awareness of the brand in 2019, Myntra.com released a new brand campaign, on TV, that specializes in the mantra, "A fashionable new age". The campaign introduced various features like Visual Search, that permits users to click an image of any merchandise and look for it on the Myntra platform.

\section{Methodology}

A questionnaire was designed to understand about the strategies used by Myntra to sustain relationship with their customers, and to know the awareness and effectiveness of those strategies from an individual perspective.The study adopted both qualitative and quantitative survey research method. Qualitative research survey is a less structured research methodology used to study in-depth information about the consumer's reasons and preferences accordingly. 


\section{Result \& Discussion}

\section{A Population and Sample description}

Table 1 presents Gender \& Occupation of the Respondents. For the study data was collected from people who shop from Myntra in an objective to understand the Relationship Marketing strategies used by Myntra and its effectiveness among the customers.

Table 1: Gender \& Occupation of the respondents

\begin{tabular}{|l|c|c|c|}
\hline \multicolumn{2}{|c|}{} & \multicolumn{2}{c|}{ OCCUPATION } \\
\hline Male & $44.6 \%$ & Students & $50 \%$ \\
\hline \multirow{2}{*}{ Female } & $55.4 \%$ & $\begin{array}{l}\text { Working\& Teaching } \\
\text { House Wives }\end{array}$ & $30 \%$ \\
& & $20 \%$ \\
\hline
\end{tabular}

\section{B. Open-ended questions}

Figure 1 presents the preference of online store by the customers and can be analyzed that the most preferred online shopping website is Myntra with $44.6 \%$ of respondents prefer to shop at Myntra and about 37.1\% of respondents prefer to shop at Amazon and nearly about $18.3 \%$ of respondents prefer to shop at Ajio.

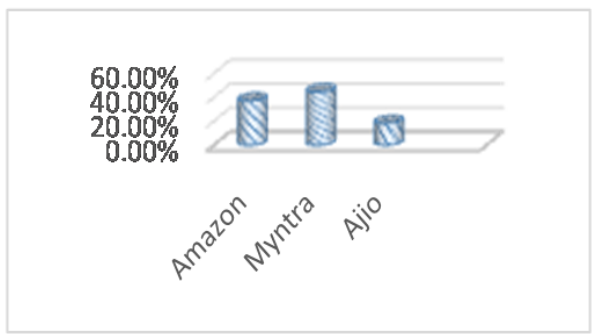

Fig 1. Preference of online store

Figure 2 presents data about Myntra's new Loyalty program "Myntra Move" features and further can be analysed that $24.3 \%$ of respondents are happy with Myntra's new loyalty program Myntra move as they can stay fit while purchasing.21.3\% of respondents says that,they get additional Myntra Insider points which benefits them in purchase. Around $16.2 \%$ of respondents says that when they receive required Myntra Insider points, they are regarded with Gift Vouchers during their purchase. 


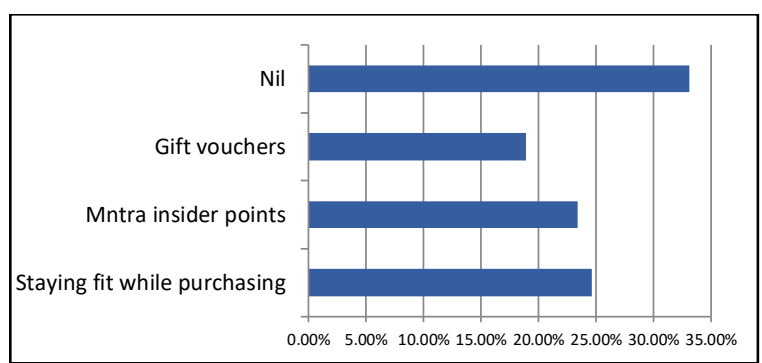

Fig2. Myntra features

\section{Likert scale questions}

Data analysis method: mean and standard deviation Table 2, 3, 4 and 5 presents' data which reaches a mean over and above the value of 3 and makes evident that, the relationship strategies used by Myntra have good effect among the consumers' decision making and buying behavior of them.

Table 2: Rating of Myntra's Impressive features

\begin{tabular}{|l|c|c|}
\hline $\begin{array}{l}\text { How easy was Myntra's Impressive } \\
\text { Features to purchase a product? }\end{array}$ & MEAN VALUE & $\begin{array}{l}\text { STANDARD } \\
\text { DEVIATION VALUE }\end{array}$ \\
\hline $\begin{array}{l}\text { Automatic search functionality for } \\
\text { filters }\end{array}$ & 3.1 & 1.01 \\
\hline Instant sending of giftcards & 3.4 & 1.11 \\
\hline Instant Product Cancellation & 3.5 & 1.01 \\
\hline
\end{tabular}

Table 3: Rating of Myntra's features

\begin{tabular}{|c|c|c|}
\hline $\begin{array}{c}\text { How would you rate the } \\
\text { features provided by Myntra? }\end{array}$ & MEAN & $\begin{array}{l}\text { STANDARD } \\
\text { DEVIATION } \\
\text { VALUE }\end{array}$ \\
\hline EasUE return and exchange & 3.7 & 0.7 \\
\hline Ease of Delivery & 3.8 & 1.09 \\
\hline Myntra Loyalty Programs & 3.5 & 0.8 \\
\hline Sales \&Offers & 3.4 & 1.01 \\
\hline
\end{tabular}

Table 4: Rating of awareness and familiarity of respondents

\begin{tabular}{|l|l|l|}
\hline QUESTIONS & MEAN VALUE & $\begin{array}{l}\text { STANDARD } \\
\text { DEVIATION VALUE }\end{array}$ \\
\hline $\begin{array}{l}\text { How familiar are you with } \\
\text { Myntra's Impressive features? }\end{array}$ & 4.35 & 0.88 \\
\hline $\begin{array}{l}\text { How well are you aware of Myntra } \\
\text { Campaign "Go Myntra La-La"? }\end{array}$ & 3.8 & 1.04 \\
\hline $\begin{array}{l}\text { How familiar are you with Myntra } \\
\text { Customer Loyalty programs? }\end{array}$ & 4.06 & 0.8 \\
\hline $\begin{array}{l}\text { How well are you satisfied with the } \\
\text { relational benefits provided by }\end{array}$ & 4.58 & 0.59 \\
\hline
\end{tabular}




\begin{tabular}{|l|l|l|}
\hline Myntra to you as its customer? & & \\
\hline $\begin{array}{l}\text { How do you rate the satisfaction } \\
\text { level of buying products from } \\
\text { Myntra? }\end{array}$ & 4.19 & 0.90 \\
\hline $\begin{array}{l}\text { How likely are you to recommend } \\
\text { Myntra online shopping website to } \\
\text { a friend or colleague? }\end{array}$ & 4.21 & 0.82 \\
\hline
\end{tabular}

Customer satisfaction is hard to achieve and even harder to maintain their retention rate, But, Myntra takes a proactive approach to understand their customer's needs and desires to excel in their customer loyalty.This study also proves that Myntra.com understands its shopper's needs and caters to them with thousands of choice of apparel, accessories, cosmetics and foot wear.It would seem as a remarkable growth strategy for Myntra by adopting its Relationship Marketing strategies and it is notable that Myntra has gained significant amount of satisfaction among the Majority of the respondents.

Table 5: Rating of benefits-Myntra Insider

\begin{tabular}{|l|c|l|}
\hline $\begin{array}{c}\text { How does Myntra } \\
\text { Insider(Myntra's Customer } \\
\text { loyalty program) benefit } \\
\text { your purchase? }\end{array}$ & MEAN & $\begin{array}{l}\text { STANDARD } \\
\text { DEVIATION } \\
\text { VALUE }\end{array}$ \\
\hline $\begin{array}{c}\text { Easy return/refund } \\
\text { policy }\end{array}$ & 3.5 & 0.99 \\
$\begin{array}{c}\text { Additional Myntra } \\
\text { points }\end{array}$ & 3.7 & 0.95 \\
\hline $\begin{array}{c}\text { Free shipping of } \\
\text { products for first 30 days }\end{array}$ & 3.68 & 0.89 \\
\hline
\end{tabular}

\section{Conclusion}

Thus, this study helped us in understanding the effectiveness of relationship marketing and its perception among the consumers. It can be observed from the study that, almost $90 \%$ of consumers who shops in Myntra are aware of Myntra's relationship marketing strategies. It is also observed that, in the era of E-tailing, majority of consumers are familiar with Myntra's loyalty program and they are also highly satisfied by the relational benefits provided by Myntra. It can be further said that, Myntra'srelational benefits for the customers allow them to make the best purchase decision, save their time, enjoy convenience and also helps to develop a friendly and close relationship with Myntra. Therefore, relationship marketing strategies should be in way that increases customer loyalty and customer retention as exhibited by Myntra.

\section{References}

[1] Hind Benouakrim, Fatima El Kandoussi, “RelationshipMarketing:Literature Review”,International Journal of Science and Research, October 2013. 
[2] John Oliver,'Relationship Marketing:The Need for Convergence In Conceptual Thinking And Validation InPractice”,Journal Of Customer Behavior, March 2006.

[3] Kunal Gaurav, "Impact of Relationship Marketing Strategy on Customer Loyalty", The Icfaian Journal of Management Research, January 2017.

[4] Laith Alrubaiee, Nahla Al-Nazer," Investigate the Impact of Relationship Marketing Orientation on Customer Loyalty: The Customer's Perspective", International Journal of Marketing Studies, April 2010.

[5] Marzo-Navarro, Pedraja-Iglesias, Rivera-Torres (2004), "The benefits of relationship marketing for the consumer and the fashion retailers", Journal of Fashion Marketing and Management, December 2004.

[6] Shilpi Kulshrestha,Madan Lal Saini," The Analytical Study ofan E-Business Model for Establishing the Concept of Customer Retention (A Case Study of Myntra.Com), Proceedings of International Conference on Advancements in Computing \& Management, September 2019. 